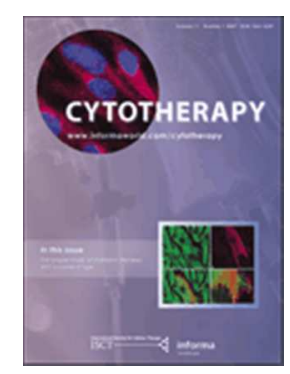

\title{
The effect of culture medium on the propagation and phenotype of corneal stroma-derived stem cells
}

\begin{tabular}{|r|l|}
\hline Journal: & Cytotherapy \\
\hline Manuscript ID: & CYTH-2015-0114.R1 \\
\hline Article Type: & Original Paper \\
\hline Date Submitted by the Author: & n/a \\
\hline Complete List of Authors: & $\begin{array}{l}\text { Sidney, Laura; University of Nottingham, Academic Ophthalmology } \\
\text { Branch, Matthew; University of Nottingham, Academic Ophthalmology } \\
\text { Dua, Harminder; University of Nottingham, Academic Ophthalmology } \\
\text { Hopkinson, Andrew; University of Nottingham, Academic Ophthalmology }\end{array}$ \\
\hline Keywords: & $\begin{array}{l}\text { Cornea, Corneal Stromal Stem Cells, Keratocytes, Mesenchymal Stromal } \\
\text { Cells, Culture Medium }\end{array}$ \\
\hline \multicolumn{2}{|c}{} \\
\hline
\end{tabular}

\section{SCHOLARONE ${ }^{\text {m }}$}

Manuscripts 
Title: The effect of culture medium on the propagation and phenotype of corneal stromaderived stem cells

Running Title: Culture of corneal stroma-derived stem cells

Authors: Laura E Sidney, Matthew J Branch, Harminder S Dua, Andrew Hopkinson

Author Affiliation: Academic Ophthalmology, Division of Clinical Neuroscience, Queen's Medical Centre Campus, University of Nottingham, UK

Corresponding Author: Dr Laura Sidney, Academic Ophthalmology, B Floor, Eye and ENT Building, Queen's Medical Campus, University of Nottingham, NG7 2UH, UK.

Tel: +44 (0)1159249924 Ext:62025

Email: laura.sidney@nottingham.ac.uk

URL: http://mc.manuscriptcentral.com/cytotherapy E-mail: cytotherapy@bellsouth.net 


\begin{abstract}
Background: The limbal area of the corneal stroma has been identified as a source of mesenchymal-like stem cells, which have potential for exploitation as a cell therapy.

However, the optimal culture conditions are disputed and few direct media comparisons have been performed. In this report, we evaluated several media types to identify the optimal for inducing an in vitro stem cell phenotype.
\end{abstract}

Methods: Primary human corneal stroma-derived stem cells (CSSC) were extracted from corneoscleral rims. Culture in seven different media types was compared: Dulbecco's modified Eagle's medium (DMEM) with 10\% foetal bovine serum (FBS); M199 with 20\% FBS; DMEM-F12 with 20\% serum replacement, basic fibroblast growth factor and leukaemia inhibitory factor (SCM); endothelial growth medium (EGM); semi-solid MethoCult ${ }^{\mathrm{TM}}$; serum-free keratinocyte medium (K-SFM); and StemPro®-34. Effect on proliferation, morphology, protein and mRNA expression were evaluated.

Results: All media supported proliferation of CSSC with the exception of K-SFM and StemPro-34. Morphology differed between media: DMEM produced large cells whereas EGM produced very small cells. Culture in M199 produced a typical mesenchymal stem cell phenotype with high expression of CD105, CD90 and CD73 but not CD34. Culture in SCM produced a phenotype more reminiscent of a progenitor cell type with expression of CD34, ABCG2, SSEA-4 and PAX6.

Discussion: Culture medium can significantly influence CSSC phenotype. SCM produced a cell phenotype closest to that of a pluripotent stem cell, and we considerate to be the most appropriate for development as a clinical grade medium for the production of CSSC phenotypes suitable for cell therapy. 
Keywords: Cornea, Corneal Stroma, Corneal Stromal Stem Cells, Keratocytes, Mesenchymal Stromal Cells, Culture Medium

\section{$\underline{\text { Abbreviations }}$}

a-SMA $\quad \alpha$-smooth muscle actin

ALDH Aldehyde dehydrogenase

bFGF Basic fibroblast growth factor

BSA Bovine serum albumin

CD Cluster of differentiation

CSSC Corneal stroma-derived stem cells

DAPI 4',6-diamidino-2-phenylindole

DMEM Dulbecco's modified Eagle's medium

ECM Extracellular matrix

EGF Epidermal growth factor

EGM Endothelial growth medium

FBS Foetal bovine serum

hESC Human embryonic stem cells

iPSC Induced pluripotent stem cells

ISCT International Society for Cellular Therapy

K-SFM Keratinocyte-serum free medium

KSR Knockout serum replacement

LIF Leukaemia inhibitory factor

M199 Medium 199

MSC Multipotent mesenchymal stromal cells

PBS Phosphate buffered saline 


$\begin{array}{ll}\text { PDGF } & \text { Platelet-Derived Growth Factor } \\ \text { RT } & \text { Room temperature } \\ \text { RT-qPCR } & \text { Quantitative reverse transcription polymerase chain reaction } \\ \text { SCM } & \text { Stem cell medium } \\ \text { TGF } & \text { Transforming growth factor }\end{array}$




\section{Introduction}

Corneal blindness is one of the leading causes of treatable vision loss worldwide [1]. Trauma to the cornea can occur from a wide range of environmental factors including chemical agents, thermal and mechanical injuries, surgical intervention, and microbial infection [2, 3]. Specialised cellular and structural organization is responsible for corneal transparency essential for normal vision [4-6]. Due to this, the cornea poses unique therapeutic challenges. Chronic donor shortages, tissue quality issues, and complications with immune rejection have propelled the development of regenerative medicine strategies for the cornea. These new treatments include the development of stem cell therapies for the treatment of ocular surface disorders.

The stroma of the cornea contains a population of cells known as keratocytes [7], which under normal healthy conditions remain quiescent and exhibit a dendritic morphology with extensive intercellular contacts $[8,9]$. Keratocytes act to maintain the structure and transparency of the stroma by producing and maintaining extracellular matrix (ECM) proteins, such as collagen and proteoglycans [10-12]. Markers traditionally used to identify the keratocyte phenotype include aldehyde dehydrogenase (ALDH), keratocan, CD133 and, as originally identified by our group, CD34 [13-15].

Keratocytes can be isolated from the stroma using collagenase treatment for ex vivo culture. However, once transferred to tissue culture plastic, the cells differentiate, and alternative cell populations emerge, dependent on the culture environment [16-18]. The extracted stromal cells "activate" and take on a fibroblastic phenotype $[19,20]$. In vivo, this "activation" is associated with response to injury, as the keratocytes adjacent to the wound begin to exhibit morphological characteristics of fibroblasts and commence tissue remodelling $[5,8]$. In severe injuries or later stages of remodelling, a myofibroblast phenotype is adopted, which 
actively secretes contractile ECM components, such as $\alpha$-smooth muscle actin ( $\alpha$-SMA). This can cause scar formation and loss of corneal transparency $[8,21]$.

In vitro, keratocytes extracted from the limbus, have been shown to display characteristics of multipotent mesenchymal stromal cells (MSC) [20, 22], that after several passages in a certain medium, conform to a criteria stipulated by the International Society for Cellular Therapy (ISCT) $[18,23]$. The extracted corneal stroma-derived stem cells (CSSC) express MSC-associated cell surface markers such as CD29, CD73, CD90 and CD105, and possess the ability to differentiate down the osteogenic, chondrogenic and adipogenic lineages in vitro $[18,24]$. Therefore, it has been hypothesized that the limbal keratocyte is an MSC progenitor found in the corneal stroma $[18,25]$. A specific population of CSSC that can be identified by side population isolation has also been described that is believed to be a keratocyte progenitor [26].

Cells extracted from the corneal stroma have previously been cultured under a number of different conditions, with the intention of either retaining keratocyte phenotype or promoting a stem cell phenotype. Traditionally, keratocytes have been cultured in Dulbecco's modified Eagle's medium (DMEM) supplemented with 10\% foetal bovine serum (FBS) [20, 27, 28], however this has been shown to produce sub-optimal culture conditions for the production of MSC [24]. Researchers have now expanded the repertoire of media that has been used for the culture of corneal stromal cells but few comparative studies between media have been performed. Culture in medium containing serum, of varying concentrations, is usually preferred. Serum has advantages as it provides a source of attachment and growth factors, allowing proliferation and rapid expansion of the cells. However, the presence of serum, or more specifically growth factors present in serum, such as transforming growth factor- $\beta 1$ (TGF- $\beta 1$ ), are reported to cause fibroblastic or myofibroblastic differentiation, characterized by a fusiform morphology and protein markers such as $\alpha$-SMA [29, 30] and CD90 [31] along 
with the loss of keratocyte markers $[5,16]$. Moreover, the addition of serum has been used to deliberately generate corneal fibroblasts rather than keratocytes [32], however, most researchers would prefer an undifferentiated/inactive phenotype. Cultures that contain a lower percentage of serum, such as $2 \%(\mathrm{v} / \mathrm{v})$, retain a keratocyte phenotype more effectively, but have much lower proliferation rates [33]. It has also been suggested that serum-free growth media developed for other cell types might also be suitable, such as the use of keratinocyte serum free medium (K-SFM) [34]. Changing the basal medium from DMEM to medium 199 (M199) or DMEM/F12, which contain a greater proportion of other components such as amino acids and nucleotides leads to the generation of a population of MSC or MSC-like cells [23, 35]. The use of M199 with the addition of 20\% FBS to culture keratocytes, generates MSC that adhere to ISCT criteria [18]. Some researchers have cultured cells in media containing recombinant growth factors such as epidermal growth factor (EGF), basic fibroblast growth factor (bFGF), platelet-derived growth factor (PDGF) and leukaemia inhibitory factor (LIF), in lieu of serum [32, 36, 37], in order to get a cell phenotype more indicative of a pluripotent stem cell. While this may prove more easily translatable to the clinic compared to serum, the addition of recombinant growth factors, both in research and clinically, can be costly. In addition, keratocytes express CD34 in vivo [14, 15], a marker commonly associated with haematopoietic stem cells, which might suggest that the use of culture media traditionally used to support cells of haematopoietic origin might be suitable.

Herein, we compare the properties of cultured CSSC in seven different media formulations to identify the media that best promotes an in vitro stem cell phenotype. We investigate: two FBS-containing media, DMEM with 10\% FBS and M199 with 20\% FBS; a medium more associated with the culture of pluripotent stem cells containing bFGF and LIF (Stem Cell Medium, SCM); a medium designed for the growth of endothelial cells, but previously used for the culture of pluripotent stem cells (EGM) [38]; a serum-free medium (K-SFM); and two 
media developed for the culture of haematopoietic cells, one semi-solid (MethoCult ${ }^{\mathrm{TM}}$ ) and one liquid (StemPro®-34).

1

2

5

6

7

8

9

10

11

12

13

14

15

16

17

18

19

20

21

22

23

24

25

26

27

28

29

30

31

32

33

34

35

36

37

38

39

40

41

42

43

44

45

46

47

48

49

50

51

52

53

54

55

56

57

58

59

60

URL: http://mc.manuscriptcentral.com/cytotherapy E-mail: cytotherapy@bellsouth.net 


\section{Materials and Methods}

\section{Tissue}

Human corneal tissue for research was obtained from Manchester or Bristol Eye Banks subject to a Materials Transfer Agreement. Use of human donor tissue was used with approval by the local ethics research committee and in accordance with the tenets of the Declaration of Helsinki, following consent obtained from the donors and/or their relatives.

\section{Isolation and culture of primary human corneal stromal stem cells}

Human corneal stromal stem cells (CSSC) were isolated from corneal rims, using a modification of a previously described method [23]. Excess sclera was removed and the epithelium and endothelium detached by gentle scraping. Remaining stromal tissue was divided into small pieces and digested in $1 \mathrm{mg} / \mathrm{mL}$ collagenase Type IA (Sigma Aldrich, Gillingham, UK) for 7 hours at $37^{\circ} \mathrm{C}$. Digests were filtered through a $40 \mu \mathrm{m}$ cell strainer before being centrifuged and resuspended in appropriate medium. CSSC were continually cultured in one of seven media types (table 1). CSSC from each donor were separated between all media, to allow for a true comparison of media effects, without donor-to-donor variation. Cells in all media were cultured on surfaces coated with $0.1 \%$ (v/v) gelatin (Sigma Aldrich) and incubated in a humidified environment at $37^{\circ} \mathrm{C}, 5 \%(\mathrm{v} / \mathrm{v}) \mathrm{CO}_{2}$, with the respective medium changed every 2-3 days. Cells were passaged using treatment with TrypLE ${ }^{\mathrm{TM}}$ Express dissociation reagent and seeded at 3,000 cells $/ \mathrm{cm}^{2}$ (Life Technologies, Paisley, UK).

\section{Cell proliferation and viability}


Cell proliferation and viability was assessed by PrestoBlue ${ }^{\mathrm{TM}}$ Cell Viability Reagent (Life Technologies). Cells at passage 0 (P0) were seeded at 1000 cells/well in 96-well plates. On days $1,3,7$, and 10 media was aspirated, cells washed in phosphate buffered saline (PBS), and $100 \mu \mathrm{L}$ fresh medium applied. Subsequently, $10 \mu \mathrm{L}$ PrestoBlue ${ }^{\mathrm{TM}}$ Cell Viability Reagent was added to each well and incubated for 20 minutes at $37^{\circ} \mathrm{C}$. Aliquots of $100 \mu \mathrm{L}$ were transferred to black 96-well plates and samples were rinsed in PBS and returned to culture in the appropriate medium. Fluorescence readings were taken at excitation $560 \mathrm{~nm} / \mathrm{emission} 590$ nm using an Infinite ${ }^{\circledR} 200$ Pro microplate reader (Tecan, Reading, UK) and results were corrected for background fluorescence from medium-only controls. Cell number was discerned by standard curve.

\section{Fluorescent immunocytochemistry}

Cell samples for immunocytochemistry were cultured in gelatin-coated glass chamber slides (Nunc Lab-Tek, Thermo Fisher Scientific, Loughborough, UK). Cells were fixed in a 4\% $(w / v)$ solution of buffered paraformaldehyde (Sigma Aldrich) for 10 minutes. After washing in PBS cells were permeabilised where appropriate, in 0.1\% ( $v / v)$ Triton X-100 (Sigma Aldrich) for 5 minutes with subsequent washing in PBS. Blocking of non-specific protein binding was performed for 1 hour at room temperature (RT) in PBS with $1 \%(v / v)$ bovine serum albumin (BSA, Sigma Aldrich), 0.3 M glycine (Sigma Aldrich) and 3\% (v/v) donkey serum (Sigma Aldrich). Samples were incubated with primary antibodies at $4^{\circ} \mathrm{C}$ overnight (see table 2 for antibody details). After washing with PBS, samples were incubated with secondary antibodies (table 2) for one hour at RT. Counterstaining with Alexa-Fluor 488 conjugated phalloidin (dilution 1:40, New England Biolabs, Hitchin, UK) to stain F-actin was performed for 20 minutes at RT, before washing. Samples were also counterstained with 0.5 
$\mu \mathrm{g} / \mathrm{mL}$ 4',6-diamidino-2-phenylindole (DAPI; Santa Cruz Biotechnology, Heidelberg, Germany) for 10 minutes. Chambers were removed and slides were mounted in fluorescence mounting medium (Dako, Ely, UK) before imaging. Negative controls were performed by omitting the primary antibody.

Immunocytochemistry was quantified using Image $\mathrm{J}$ software version 1.46r. Total number of cells was determined using DAPI images. Image was converted to binary, a watershed was applied and the number of particles analysed, to calculate the number of stained nuclei. The number of antigen-positive cells were then determined manually using the inbuilt cell counter plugin, and a percentage of positive stained cells calculated.

\section{Microscopy and imaging}

Phase contrast imaging was performed on a Leica DM-IRB inverted microscope, and images captured with a Hammatsu digital camera and Volocity imaging software (Improvision, Coventry, UK). Fluorescent immunocytochemistry samples were cultured on glass chamber slides and viewed using an upright fluorescence microscope (BX51, Olympus, Southend-onSea, UK) with images captured with a black and white camera (XM-10, Olympus) and Cell $^{\wedge} \mathrm{F}$ software (Olympus).

\section{Quantitative Reverse Transcription Polymerase Chain Reaction (RT-qPCR)}

Cells were lysed at P2 and the lysate was homogenized using QIAshredder columns (Qiagen, Manchester, UK). Total RNA was extracted using an RNeasy mini kit (Qiagen) according to manufacturer's instructions. RNA quantity was measured using a NanoDrop spectrophotometer. $1 \mu \mathrm{g}$ of RNA was transcribed into single stranded cDNA using 
Superscript III reverse transcriptase (Life Technologies) with random hexamer primers, according to manufacturer's instructions. For PCR reactions, $1 \mu \mathrm{L}$ of cDNA was used with inventoried Taqman assays (Applied Biosystems, Life Technologies) to detect GAPDH (Hs99999905_m1), CD34 (Hs00990732_m1), THY1 (Hs00174816_m1), POU5F1 (Hs00999634_gH), PAX6(Hs00240871_m1), ALDH3A1 (Hs00964880_m1), ACTA2 (Hs00909449_m1), KERA (Hs00559942_m1) and COL1A1 (Hs00164004_m1). Amplification was performed on an Mx3005P multicolour 96-well PCR system (Stratagene, Agilent Technologies, Stockport, UK). RT-qPCR reactions were analysed using the Real Time PCR Miner algorithm [39] which calculates efficiency and threshold cycle. All experimental values were normalised to readings of the endogenous reference gene GAPDH.

\section{Differentiation of CSSC to a keratocyte phenotype}

CSSC were grown in different media to P2 and subsequently seeded in 6-well plates and glass chamber slides at $20,000 \mathrm{cells} / \mathrm{cm}^{2}$. Cells were maintained in their respective culture media for 3 days before being changed to keratocyte differentiation media for 21 days. Keratocyte differentiation media consisted of DMEM/F12 supplemented with $50 \mu \mathrm{g} / \mathrm{mL}$ ascorbate 2-phosphate (Sigma-Aldrich), $10 \mu \mathrm{g} / \mathrm{mL}$ human insulin, $5.5 \mu \mathrm{g} / \mathrm{mL}$ human transferrin, $6.7 \mathrm{ng} / \mathrm{mL}$ sodium selenite (combination, Life Technologies), $1 \%$ non-essential amino acids (Life Technologies), $10 \mathrm{ng} / \mathrm{mL}$ bFGF (Life Technologies) and $20 \mathrm{ng} / \mathrm{mL}$ gentamicin, $0.5 \mathrm{ng} / \mathrm{mL}$ amphotericin B (Life Technologies). Non-differentiated controls were maintained in their culture media.

\section{Statistical Analysis}

URL: http://mc.manuscriptcentral.com/cytotherapy E-mail: cytotherapy@bellsouth.net 
Statistical significances were analysed using GraphPad Prism version 6.02. One-way

ANOVA was used to compare multiple groups with post-hoc Dunnett's multiple comparison test. 


\section{$\underline{\text { Results }}$}

\section{Effect of different media on proliferation of CSSC}

Effects of the seven media on CSSC proliferation and viability were tested at P0 (figure 1). CSSC proliferation was slow in standard DMEM over 10 days (figure 1b). Considerably higher proliferation rates were seen in M199 (figure 1c), SCM (figure 1d) and EGM (figure 1e). However, in EGM, viability dropped after day 7, when the cells reached confluence. Cells cultured in MethoCult (figure 1f) adhered to the bottom of the well, despite the semisolid medium and divided slowly, not proliferating significantly until after day 7. Cells in KSFM did not proliferate at all, but there were still viable cells at day 10. The StemPro-34 medium did not support CSSC proliferation, as there were no viable cells adhered to the plate by day 7 .

\section{Effects of different media on morphology of CSSC}

Effects of the seven initial media types were compared by imaging CSSC morphology at P0, after 5 days of culture in the respective media (figure 2). Phase contrast imaging showed that there were subjectively lower numbers of cells in DMEM (a) and MethoCult (e) than M199 (b), SCM (c) and EGM (d). There were very few cells in K-SFM (f) and in StemPro-34 (g), the cells had begun to become rounded and detach from the plate, a process commonly seen with loss of viability. F-actin (figure 2B) and vimentin (figure 2C) staining demonstrated differences in morphology between the cell cultures. Cells in M199 and EGM began to align spontaneously with each other. Cells cultured in DMEM were much larger and spread over a greater area. Cells cultured in M199 had strong vimentin staining with filaments circling the nucleus and actin filaments at the cell periphery and stretched across the cell. Cells in SCM 
were smaller than M199, and appeared to contain a higher proportion of actin fibres. Cells in EGM were the smallest cells, had aligned with each other and did not have vimentin rings around the nucleus. When cultured in MethoCult, CSSC had a more heterogenous appearance with cells of many sizes. CSSC in both K-SFM and StemPro-34 were sparse, individual cells displaying a vimentin and actin cytoskeleton. However, there were too few cells in these media to determine differences in morphology. Low magnification images of actin/vimentin indicated the density of the cell monolayer, with M199 and SCM having the densest monolayers at day 7 .

\section{Effect of different media on protein expression of CSSC}

CSSC at P2 were seeded in glass chamber slides and immunocytochemistry was performed to identify expression of key markers associated with MSC, keratocytes and pluripotent stem cells. Images were then quantified to estimate the purity of the cell populations in each media. The medium StemPro-34 was not included due to the previously demonstrated rapid loss of cell viability. Figure 3 shows the expression of cluster of differentiation (CD) markers positively and negatively associated with MSC. Figure 4 shows the quantification of these markers. CD34 expression is typically considered a marker absent on MSC; however, it is also a keratocyte marker. CD34 expression can clearly be seen in individual cells in EGM and K-SFM, and in a number of cells in SCM. CD34 staining was not observed in DMEM, M199 and MethoCult. CD105, CD90 and CD73 are markers of MSC. The percentage of cells expressing CD34 was significantly higher in SCM and K-SFM than all other media and when quantified, CD34 was stained in approximately $55.2 \%$ cells in SCM and $72.7 \%$ cells in KSFM (figure 4A). CD105 was observed on all cells in all media and the merged image with CD34 shows the individual cells that are expressing CD34 also express CD105. There were 
no significant differences between percentages of cells expressing CD105 in different media, with nearly $100 \%$ of cells expressing CD105 in each media (figure 4B). CD90 staining was strong in M199, SCM and K-SFM. However, it was not present in EGM and only appeared in some cells in DMEM and MethoCult. Quantification of the percentage of cells stained for CD90 revealed that there were significantly higher numbers in M199 (97.4\%), SCM (99.8\%) and K-SFM (97.4\%), than DMEM (46.8\%), EGM (36.8\%) and MethoCult (71.1\%). CD73 was seen in all cells in every medium and all media had approximately $100 \%$ of cells staining for CD73

Immunocytochemistry was performed for a range of other markers associated with keratocytes and stem cells (figure 5) and subsequently quantified (figure 6). ABCG2 was detected in over $80 \%$ of cells in SCM (90.2\%), EGM (98.5\%), MethoCult (87.1\%) and KSFM (83.3\%), and to a lesser degree in the FBS-containing media DMEM (62.9\%) and M199 (11.6\%). Keratocan, a proteoglycan secreted by keratocytes, was detected in all cultures; however higher levels of staining were seen in cell cultured in DMEM (93.3\%), EGM (81.0\%), MethoCult (62.8\%)and K-SFM (90.3\%), than in SCM (36.8\%) and M199 (10.6\%). SSEA-4, a cell surface marker found on pluripotent stem cells was seen to a high degree in $\operatorname{SCM}(72.4 \%)$ and EGM (75.0\%) but to a lesser degree in DMEM (37.5\%), M199 (13.3\%), MethoCult (9.0\%)and K-SFM (12.0\%). Oct-4A, a transcription factor associated with pluripotent stem cells was seen in almost all the nuclei of cells cultured in M199 (93.8\%), SCM (94.1\%), EGM (92.3\%)and MethoCult (96.1\%), but in only half of DMEM (51.6\%) and very few in K-SFM (5.6\%). PAX6 was seen predominantly in SCM (86.8\%), EGM (98.5\%), MethoCult (68.2\%) and K-SFM (76.7\%).

\section{Effect of different media on mRNA expression of CSSC}

URL: http://mc.manuscriptcentral.com/cytotherapy E-mail: cytotherapy@bellsouth.net 
RT-qPCR was performed on CSSC at P2 to determine relative differences in mRNA level of CD34, THY1 (gene name for CD90), POU5F1 (gene name for Oct-4) and PAX6 (figure 7). CD34, THY1 and PAX6 mRNA level was significantly higher in SCM than in any other medium. For CD34 and THY1 there were no other significant differences in mRNA levels between DMEM, M199, EGM and MethoCult. POU5F1 was downregulated in MethoCult compared to DMEM, but no differences were seen between the other media. PAX6 was downregulated in M199, EGM and MethoCult, when compared to DMEM.

\section{Effect of differentiation on keratocyte differentiation}

CSSC that had been cultured in different media up to P2 were changed to a serum-free keratocyte differentiation media for 21 days. Immunocytochemistry and RT-qPCR were performed to assess levels of differentiation compared to non-differentiated controls (figure 8). Immunocytochemistry showed increased levels of ALDH3A1 in all media (fig. 8A vi-x). However, CSSC, in SCM, EGM and MethoCult appeared to contain higher levels of ALDH3A1 in the non-differentiated controls (fig. 8A i-v). Myofibroblast marker $\alpha$-SMA was present in both the control and differentiated samples in DMEM (fig. 8B i/vi) and M199 (fig. 8B ii/vii). Non-differentiated controls in SCM contained some cells expressing $\alpha$-SMA (fig. 8Biii) but these were not present in the differentiated sample (fig. 8Bviii). CSSC cultured in EGM media, showed the reverse, with no staining for $\alpha$-SMA in control samples (fig. 8Biv) but increased staining in the differentiated samples (fig. 8Bix). No $\alpha$-SMA was seen in MethoCult samples. Staining for CD34 was increased in the differentiation samples for all media (fig. $8 \mathrm{C}$ vi-x). However, SCM controls also contained some cells that stained for CD34. RT-qPCR showed that $A L D H 3 A 1$ was significantly increased in differentiated CSSC from DMEM, M199, and SCM culture compared to controls, but not in EGM or MethoCult 
(fig. 8D). ACTA2 (gene name for $\alpha$-SMA) was significantly increased in both DMEM and EGM cells when differentiated, and was not significantly decreased in differentiated cells from any media (fig. 8E). CD34 expression was increased in differentiated cells in all media, but only significantly in SCM and MethoCult (fig. 8F). Increased mRNA levels of KERA (gene name for keratocan, fig. 8G) and COL1A1 (collagen-I, fig. 8H) were seen in differentiated cells from all media, but were increased significantly in cells propagated in SCM, EGM and MethoCult, indicating increased ECM production.

\section{$\underline{\text { Discussion }}$}

Corneal reconstruction with amniotic membrane $[40,41]$ has demonstrated that the acellular amniotic stroma is repopulated by corneal keratocytes that migrate from the stroma through breaks in the Bowman's membrane. These cells are initially CD34 negative but $\alpha$-SMA and vimentin positive, indicating that they are an "activated" phenotype. When corneal buttons were obtained from corneal grafts performed around 9 to 12 months subsequent to the amniotic membrane graft, several cells in the amnion stroma were positive for CD34, indicating that immunophenotypical transitions occur over time during corneal regeneration in vivo [40]. This holds promise for use of in vitro expanded CSSC in cell therapies for corneal regeneration.

As the potential for the application of regenerative cell therapies for the cornea is realised and research gathers momentum, it is essential that common denominators are established in relation to methodology, so that outcomes are comparable and understood by all. Culture media constituents and respective concentrations can influence cell behaviour and differentiation. Hence, even if we start with an identical cell population, different media and culture environments will result in different cell populations after extended culture, although 
most or all are collectively referred to as 'progenitor or stem cells'. This study, wherein a comprehensive comparison of CSSC media was undertaken concerning cell morphology, proliferation, protein and gene expression, and keratocyte differentiation ability addresses this issue by identifying an optimal medium and an optimal in vitro progenitor cell phenotype, with the potential to generate keratocytes. For the purposes of this study, we considered an optimal culture medium to have the following properties: the ability to maintain viability and proliferation of the CSSC in a moderate manner; the promotion of stem cell characteristics including typical markers for progenitor and pluripotent stem cells; and the ability to allow differentiation back to a keratocyte phenotype. If the cell were to become part of a cell therapy, the optimal medium would also need to allow easy transition to a clinical manufacturing process. For this reason, media containing FBS would be unsuitable due to its animal origin and variable non-defined composition.

Our results demonstrate that when an extracted cell population is divided into different media, the resulting cultured cell populations show very different characteristics. Although, some markers such as vimentin, ALDH3A1, CD73 and CD105 were conserved across all media, these markers are associated with fibroblasts and MSC and may potentially be induced by culture on two-dimensional plastic surfaces. This also suggests that the cells fundamentally express a range of baseline markers in vitro, but changing the medium or supplements can cause additional markers to be either maintained or expressed, such as ABCG2, CD34 and PAX6.

Previous media comparison studies have focused solely on the production and maintenance of an MSC phenotype in CSSC [23, 24], as defined by the ISCT [42]. However, the current minimal criteria for MSC are not ideal for assessing the phenotype of CSSC, as one criterion states that MSC should not express CD34. Nevertheless, our group has showed CD34 is a well-established marker for quiescent keratocytes in vivo [14, 15], and CD34 has been linked 
to the stem-cell properties of CSSC and other potentially related cell types [23, 43]. The function of CD34 expression in keratocytes has not yet been elucidated, although it has been speculated that CD34 plays roles in regulation of differentiation, adhesion and quiescence $[14,43]$. It has been suggested that CD $34^{+}$keratocytes are of hematopoietic origin [27], however, these cells do not form hematopoietic colonies when cultured in semi-solid medium, as shown by culture in MethoCult in this study, and in reality display a plastic adherent, fibroblastic morphology [18]. For these reasons, a medium that satisfies the minimum criteria for an MSC phenotype, such as M199, may not be as desirable for culture of CSSC as, for example SCM, a medium that promotes markers associated with an MSC phenotype (CD73, CD90, CD105), alongside other progenitor/stem cell markers, such as CD34, ABCG2, PAX6, Oct-4, and SSEA-4.

ABCG2 is a molecular determinant of the side population phenotype that is characteristic of stem cells, and has been used previously to identify CSSC $[26,44]$. ABCG2 is expressed by a wide variety of stem cells including haematopoietic stem cells [45], embryonic stem cells [46], neural stem cells [47], and perhaps most relevantly limbal epithelial stem cells [48]. ABCG2 is often downregulated during stem cell differentiation [44], suggesting that it plays a regulatory role in maintaining stem cells in an undifferentiated state. PAX6, although not conventionally a stem or progenitor marker, is strongly associated with eye development. PAX6 has also been associated with keratocyte progenitors [49]. SSEA-4 and OCT-4 are markers that are used to identify human pluripotent stem cells [50]. However, these markers have also been found on adult stem cells including MSC [51]. The presence of all these markers on the cells in SCM suggests a level of plasticity, which more differentiated cells may not possess. This plasticity will allow the exploitation of CSSC as cellular therapies, either to repopulate the corneal stroma as keratocytes, or in broader regenerative medicine areas, as they are a readily available and easy to isolate stem cell source. 
Many researchers are aiming to use CSSC as part of regenerative cellular therapies. For this purpose, CSSC would need to be expanded in large quantities whilst maintaining the desired phenotype. This would rule out the use of any medium similar to K-SFM or StemPro-34. DMEM and MethoCult also had slow proliferation rates, so it would be unlikely that media similar to either of these would be used. The use of DMEM in particular, seemed to favour a characteristic fibroblastic phenotype, with very large cells and low expression of CD34, CD90, ABCG2 and SSEA-4. Cells in MethoCult had a more heterogeneous appearance that may have signified different populations of differentiating cells potentially caused by the inclusion of factors such as interleukin-3 and erythropoietin in the medium. Growth factors such as bFGF, PDGF, and isoforms of TGF- $\beta$ have all been associated with regulation of wound healing and a keratocyte phenotype in the corneal stroma [52, 53].

Ingredients within a basal medium can have a large effect on the final cell phenotype. Comparisons between the DMEM and M199 formulations reveals that M199 contains a number of constituents not found in DMEM including numerous pyrimidines and purines including ATP, ribose, cholesterol and vitamins which likely drive proliferation [54]. M199 contains the same amount of D-glucose as DMEM 'low glucose' formulations (1000 mg/L) whereas the 'high glucose' DMEM used in this study contains significantly higher concentrations $(4500 \mathrm{mg} / \mathrm{L})$. This indicates that the much faster proliferation rates seen in M199 compared to DMEM was not down to glucose concentration.

The success of SCM in promoting markers associated with progenitor cells and pluripotency is most likely because it is a medium predominantly used in the culture of human embryonic stem cells (hESC) and induced pluripotent stem cells (iPSC). SCM does not contain FBS but instead uses knockout serum replacement (KSR). In cultures of hESC and iPSC, FBS is not suitable as it is an undefined biological product, which varies from batch-to-batch, and can trigger spontaneous differentiation of cells. KSR is chemically defined and the composition 
can be found in its patent [55] and in this publication by Garcia-Gonzalo and Belmonte [56]. KSR predominantly contains a mix of amino acids, vitamins, antioxidants, trace elements, insulin, transferrin and lipid-rich albumin, which has been shown to be the ingredient most involved in regulation of pluripotency [56]. SCM also contains the recombinant proteins bFGF and LIF. bFGF is associated with differentiation to the keratocyte phenotype [57] and is essential for the maintenance of pluripotency of hESC [58]. LIF is a factor that is essential in the maintenance of pluripotency in mouse ESC [59] but has also been identified as important in naïve hESC [60]. The combination of these ingredients may allow SCM to induce or maintain a naïve or progenitor phenotype within the CSSC population. SCM was the most successful propagation medium in studies assessing the ability to differentiate back to a keratocyte in vitro. This may be because SCM retained markers associated with the keratocyte phenotype more successfully than the other media types.

From those tested, we have identified SCM as being the medium with the most potential for cell therapy applications; however in its current form it would still not be ideal for the clinical production of CSSC as it is not completely free of animal derived products (xeno-free). However, all the ingredients have available xeno-free alternatives, which are currently expensive, and would add to the cost of research and clinical translation. It is also worth noting that although the culture medium is important in deriving a phenotype of choice; other aspects of in vitro cell culture can have an effect. Culturing in a three-dimensional environment rather than two-dimensional can help to dedifferentiate cells back to their original form [61], thus changing to a scaffold based culture method may have an additional effect on top of culture medium. Other changes to the environment can include the use of hypoxia, which has been shown to induce faster proliferation whilst maintaining stem cell potential and delaying the cellular ageing process [62]. However, culture in a threedimensional environment can be complicated and have many unpredictable effects on the 
cells, and a hypoxic environment has been shown to promote chondrogenic differentiation, which may be an issue as the cells are of mesenchymal origin [63, 64].

This study has shown that there can be considerable variation in the properties of CSSC when cultured in different media. This indicates that in many cases, studies between groups may not be comparable if performed in different media, due to induced variations in final phenotype. For the eventual aim of producing a cell therapy from CSSC, it will be imperative to find a medium that supports a stem cell phenotype and in which the cells can be stably expanded and maintained as stocks in tissue banks, for release when required for clinical use.

\section{$\underline{\text { Acknowledgements }}$}

This work was funded by grants from the Royal College of Surgeons of Edinburgh and Fight for Sight. This study was supported by COST Action BM1302 Joining Forces in Corneal Regeneration Research.

\section{Disclosure of Interests}

The authors report no conflicts of interest.

\section{$\underline{\text { References }}$}

[1] Whitcher JP, Srinivasan M,Upadhyay MP, Corneal blindness: a global perspective. Bull World Health Organ 2001; 79: 214-21.

[2] Tabbara KF, Blindness in the eastern Mediterranean countries. Br J Ophthalmol 2001; 85: 771-5.

[3] Dua HS, Miri A,Said DG, Contemporary limbal stem cell transplantation - a review. Clin Experiment Ophthalmol 2010; 38: 104-17. 
[4] Jester JV, Petroll WM,Cavanagh HD, Corneal stromal wound healing in refractive surgery: the role of myofibroblasts. Prog Retin Eye Res 1999; 18: 311-56.

[5] Funderburgh JL, Mann MM,Funderburgh ML, Keratocyte phenotype mediates proteoglycan structure: a role for fibroblasts in corneal fibrosis. J Biol Chem 2003; 278: 45629-37.

[6] Hassell JR,Birk DE, The molecular basis of corneal transparency. Exp Eye Res 2010; 91: 326-35.

[7] Hoar RM, Embryology of the eye. Environ Health Perspect 1982; 44: 31-4.

[8] West-Mays JA,Dwivedi DJ, The keratocyte: corneal stromal cell with variable repair phenotypes. Int J Biochem Cell Biol 2006; 38: 1625-31.

[9] Poole CA, Brookes NH,Clover GM, Keratocyte networks visualised in the living cornea using vital dyes. J Cell Sci 1993; 106 ( Pt 2): 685-91.

[10] Meek KM,Boote C, The organization of collagen in the corneal stroma. Exp Eye Res 2004; 78: 503-12.

[11] Scott JE,Thomlinson AM, The structure of interfibrillar proteoglycan bridges (shape modules') in extracellular matrix of fibrous connective tissues and their stability in various chemical environments. J Anat 1998; 192 ( Pt 3): 391-405.

[12] Michelacci YM, Collagens and proteoglycans of the corneal extracellular matrix. Braz J Med Biol Res 2003; 36: 1037-46.

[13] Jester JV, Moller-Pedersen T, Huang J, Sax CM, Kays WT, Cavangh HD, et al., The cellular basis of corneal transparency: evidence for 'corneal crystallins'. J Cell Sci 1999; 112 ( Pt 5): 613-22.

[14] Joseph A, Hossain P, Jham S, Jones RE, Tighe P, McIntosh RS, et al., Expression of CD34 and L-selectin on human corneal keratocytes. Invest Ophthalmol Vis Sci 2003; 44: 4689-92.

[15] Perrella G, Brusini P, Spelat R, Hossain P, Hopkinson A,Dua HS, Expression of haematopoietic stem cell markers, CD133 and CD34 on human corneal keratocytes. Br J Ophthalmol 2007; 91: 94-9.

[16] Beales MP, Funderburgh JL, Jester JV,Hassell JR, Proteoglycan synthesis by bovine keratocytes and corneal fibroblasts: maintenance of the keratocyte phenotype in culture. Invest Ophthalmol Vis Sci 1999; 40: 1658-63.

[17] Masur SK, Dewal HS, Dinh TT, Erenburg I,Petridou S, Myofibroblasts differentiate from fibroblasts when plated at low density. Proc Natl Acad Sci U S A 1996; 93: 4219-23.

[18] Branch MJ, Hashmani K, Dhillon P, Jones DR, Dua HS,Hopkinson A, Mesenchymal stem cells in the human corneal limbal stroma. Invest Ophthalmol Vis Sci 2012; 53: 5109-16.

[19] Du Y, Carlson EC, Funderburgh ML, Birk DE, Pearlman E, Guo N, et al., Stem cell therapy restores transparency to defective murine corneas. Stem Cells 2009; 27: 1635-42.

[20] Choong PF, Mok PL, Cheong SK, Then KY, Mesenchymal stromal cell-like characteristics of corneal keratocytes. Cytotherapy 2007; 9: 252-8.

[21] Helary C, Ovtracht L, Coulomb B, Godeau G,Giraud-Guille MM, Dense fibrillar collagen matrices: a model to study myofibroblast behaviour during wound healing. Biomaterials 2006; 27: 4443-52.

[22] Polisetty N, Fatima A, Madhira SL, Sangwan VS,Vemuganti GK, Mesenchymal cells from limbal stroma of human eye. Mol Vis 2008; 14: 431-42.

[23] Hashmani K, Branch MJ, Sidney LE, Dhillon PS, Verma M, McIntosh OD, et al., Characterisation of corneal stromal stem cells with the potential for epithelial transdifferentiation. Stem Cell Res Ther 2013; 4: 75.

[24] Bray LJ, Heazlewood CF, Atkinson K, Hutmacher DW, Harkin DG, Evaluation of methods for cultivating limbal mesenchymal stromal cells. Cytotherapy 2012; 14: 936-47. 
[25] Li GG, Zhu YT, Xie HT, Chen SY,Tseng SC, Mesenchymal stem cells derived from human limbal niche cells. Invest Ophthalmol Vis Sci 2012; 53: 5686-97.

[26] Pinnamaneni N,Funderburgh JL, Concise review: Stem cells in the corneal stroma. Stem Cells 2012; 30: 1059-63.

[27] Sosnova M, Bradl M,Forrester JV, CD34+ corneal stromal cells are bone marrow-derived and express hemopoietic stem cell markers. Stem Cells 2005; 23: 507-15.

[28] Ainscough SL, Linn ML, Barnard Z, Schwab IR,Harkin DG, Effects of fibroblast origin and phenotype on the proliferative potential of limbal epithelial progenitor cells. Exp Eye Res 2011; 92: 10-9.

[29] Jester JV, Barry-Lane PA, Cavanagh HD,Petroll WM, Induction of alpha-smooth muscle actin expression and myofibroblast transformation in cultured corneal keratocytes. Cornea 1996; 15: 505-16.

[30] Park SH, Kim KW, Chun YS,Kim JC, Human mesenchymal stem cells differentiate into keratocyte-like cells in keratocyte-conditioned medium. Exp Eye Res 2012; 101: 16-26.

[31] Pei Y, Sherry DM,McDermott AM, Thy-1 distinguishes human corneal fibroblasts and myofibroblasts from keratocytes. Exp Eye Res 2004; 79: 705-12.

[32] Basu S, Hertsenberg AJ, Funderburgh ML, Burrow MK, Mann MM, Du Y, et al., Human limbal biopsy-derived stromal stem cells prevent corneal scarring. Sci Transl Med 2014; 6: 266ra172.

[33] Du Y, Funderburgh ML, Mann MM, SundarRaj N,Funderburgh JL, Multipotent stem cells in human corneal stroma. Stem Cells 2005; 23: 1266-75.

[34] Kawakita T, Espana EM, He H, Smiddy R, Parel JM, Liu CY, et al., Preservation and expansion of the primate keratocyte phenotype by downregulating TGF-beta signaling in a low-calcium, serum-free medium. Invest Ophthalmol Vis Sci 2006; 47: 1918-27.

[35] Garfias Y, Nieves-Hernandez J, Garcia-Mejia M, Estrada-Reyes C,Jimenez-Martinez MC, Stem cells isolated from the human stromal limbus possess immunosuppressant properties. Mol Vis 2012; 18: 2087-95.

[36] Li GG, Chen SY, Xie HT, Zhu YT, Tseng SC, Angiogenesis potential of human limbal stromal niche cells. Invest Ophthalmol Vis Sci 2012; 53: 3357-67.

[37] Katikireddy KR, Dana R,Jurkunas UV, Differentiation potential of limbal fibroblasts and bone marrow mesenchymal stem cells to corneal epithelial cells. Stem Cells 2014; 32: 71729.

[38] Kopher RA, Penchev VR, Islam MS, Hill KL, Khosla S,Kaufman DS, Human embryonic stem cell-derived CD34+ cells function as MSC progenitor cells. Bone 2010; 47: 718-28.

[39] Zhao S,Fernald RD, Comprehensive algorithm for quantitative real-time polymerase chain reaction. J Comput Biol 2005; 12: 1047-64.

[40] Said DG, Nubile M, Alomar T, Hopkinson A, Gray T, Lowe J, et al., Histologic features of transplanted amniotic membrane: implications for corneal wound healing. Ophthalmology 2009; 116: 1287-95.

[41] Nubile M, Dua HS, Lanzini M, Ciancaglini M, Calienno R, Said DG, et al., In vivo analysis of stromal integration of multilayer amniotic membrane transplantation in corneal ulcers. Am J Ophthalmol 2011; 151: 809-22 e1.

[42] Dominici M, Le Blanc K, Mueller I, Slaper-Cortenbach I, Marini F, Krause D, et al., Minimal criteria for defining multipotent mesenchymal stromal cells. The International Society for Cellular Therapy position statement. Cytotherapy 2006; 8: 315-7.

[43] Sidney LE, Branch MJ, Dunphy SE, Dua HS,Hopkinson A, Concise review: evidence for CD34 as a common marker for diverse progenitors. Stem Cells 2014; 32: 1380-9. 
[44] Ding XW, Wu JH,Jiang CP, ABCG2: a potential marker of stem cells and novel target in stem cell and cancer therapy. Life Sci 2010; 86: 631-7.

[45] Scharenberg CW, Harkey MA,Torok-Storb B, The ABCG2 transporter is an efficient Hoechst 33342 efflux pump and is preferentially expressed by immature human hematopoietic progenitors. Blood 2002; 99: 507-12.

[46] Apati A, Orban TI, Varga N, Nemeth A, Schamberger A, Krizsik V, et al., High level functional expression of the ABCG2 multidrug transporter in undifferentiated human embryonic stem cells. Biochim Biophys Acta 2008; 1778: 2700-9.

[47] Islam MO, Kanemura Y, Tajria J, Mori H, Kobayashi S, Hara M, et al., Functional expression of ABCG2 transporter in human neural stem/progenitor cells. Neurosci Res 2005; 52: 75-82.

[48] Watanabe K, Nishida K, Yamato M, Umemoto T, Sumide T, Yamamoto K, et al., Human limbal epithelium contains side population cells expressing the ATP-binding cassette transporter ABCG2. FEBS Lett 2004; 565: 6-10.

[49] Funderburgh ML, Du Y, Mann MM, SundarRaj N,Funderburgh JL, PAX6 expression identifies progenitor cells for corneal keratocytes. Faseb J 2005; 19: 1371-3.

[50] Adewumi O, Aflatoonian B, Ahrlund-Richter L, Amit M, Andrews PW, Beighton G, et al., Characterization of human embryonic stem cell lines by the International Stem Cell Initiative. Nat Biotechnol 2007; 25: 803-16.

[51] Riekstina U, Cakstina I, Parfejevs V, Hoogduijn M, Jankovskis G, Muiznieks I, et al., Embryonic stem cell marker expression pattern in human mesenchymal stem cells derived from bone marrow, adipose tissue, heart and dermis. Stem Cell Rev 2009; 5: 378-86.

[52] Lim M, Goldstein MH, Tuli S,Schultz GS, Growth factor, cytokine and protease interactions during corneal wound healing. Ocul Surf 2003; 1: 53-65.

[53] Kim A, Lakshman N, Karamichos D,Petroll WM, Growth factor regulation of corneal keratocyte differentiation and migration in compressed collagen matrices. Invest Ophthalmol Vis Sci 2010; 51: 864-75.

[54] Kondo M, Yamaoka T, Honda S, Miwa Y, Katashima R, Moritani M, et al., The rate of cell growth is regulated by purine biosynthesis via ATP production and $\mathrm{G}(1)$ to $\mathrm{S}$ phase transition. J Biochem 2000; 128: 57-64.

[55] Price PJ, Goldsborough MD,Tilkins ML, Embryonic stem cell serum replacement. I.P. Application, 1998, WO/1998/030679

[56] Garcia-Gonzalo FR,Izpisua Belmonte JC, Albumin-associated lipids regulate human embryonic stem cell self-renewal. PLoS One 2008; 3: e1384.

[57] Wu J, Du Y, Mann MM, Yang E, Funderburgh JL, Wagner WR, Bioengineering organized, multilamellar human corneal stromal tissue by growth factor supplementation on highly aligned synthetic substrates. Tissue Eng Part A 2013; 19: 2063-75.

[58] Xu C, Inokuma MS, Denham J, Golds K, Kundu P, Gold JD, et al., Feeder-free growth of undifferentiated human embryonic stem cells. Nat Biotechnol 2001; 19: 971-4.

[59] Williams RL, Hilton DJ, Pease S, Willson TA, Stewart CL, Gearing DP, et al., Myeloidleukemia inhibitory factor maintains the developmental potential of embryonic stem cells. Nature 1988; 336: 684-87.

[60] Gafni O, Weinberger L, Mansour AA, Manor YS, Chomsky E, Ben-Yosef D, et al., Derivation of novel human ground state naive pluripotent stem cells. Nature 2013; 504: 2826.

[61] Baker BM,Chen CS, Deconstructing the third dimension: how 3D culture microenvironments alter cellular cues. J Cell Sci 2012; 125: 3015-24.

[62] Haque N, Kasim NH,Rahman MT, Optimization of pre-transplantation conditions to enhance the efficacy of mesenchymal stem cells. Int J Biol Sci 2015; 11: 324-34. 
[63] Muller J, Benz K, Ahlers M, Gaissmaier C,Mollenhauer J, Hypoxic conditions during expansion culture prime human mesenchymal stromal precursor cells for chondrogenic differentiation in three-dimensional cultures. Cell Transplant 2011; 20: 1589-602.

[64] Markway BD, Tan GK, Brooke G, Hudson JE, Cooper-White JJ,Doran MR, Enhanced chondrogenic differentiation of human bone marrow-derived mesenchymal stem cells in low oxygen environment micropellet cultures. Cell Transplant 2010; 19: 29-42.

[65] De Francesco F, Tirino V, Desiderio V, Ferraro G, D'Andrea F, Giuliano M, et al., Human CD34/CD90 ASCs are capable of growing as sphere clusters, producing high levels of VEGF and forming capillaries. PLoS One 2009; 4: e6537.

[66] Carotta S, Pilat S, Mairhofer A, Schmidt U, Dolznig H, Steinlein P, et al., Directed differentiation and mass cultivation of pure erythroid progenitors from mouse embryonic stem cells. Blood 2004; 104: 1873-80. 
Table 1. Details of experimental culture media.

\begin{tabular}{|c|c|c|c|}
\hline Medium & $\begin{array}{l}\text { Basal } \\
\text { Medium }\end{array}$ & Supplements & Reference \\
\hline DMEM & $\begin{array}{l}\text { Dulbecco's } \\
\text { Modified } \\
\text { Eagle's } \\
\text { Medium } \\
\text { (Gibco, Life } \\
\text { Technologies) }\end{array}$ & $\begin{array}{l}10 \%(\mathrm{v} / \mathrm{v}) \text { foetal bovine serum (Sigma } \\
\text { Aldrich) } \\
2 \mathrm{mM} \text { L-glutamine (Sigma Aldrich) } \\
20 \mathrm{ng} / \mathrm{mL} \text { gentamicin, } 0.5 \mathrm{ng} / \mathrm{mL} \\
\text { amphotericin B (Life Technologies) }\end{array}$ & {$[20,27,28]$} \\
\hline M199 & $\begin{array}{l}\text { Medium } 199 \\
\text { (Sigma } \\
\text { Aldrich) }\end{array}$ & $\begin{array}{l}20 \%(\mathrm{v} / \mathrm{v}) \text { foetal bovine serum } \\
2 \mathrm{mM} \text { L-glutamine } \\
20 \mathrm{ng} / \mathrm{mL} \text { gentamicin, } 0.5 \mathrm{ng} / \mathrm{mL} \\
\text { amphotericin B }\end{array}$ & {$[18,23]$} \\
\hline $\begin{array}{l}\text { Stem Cell } \\
\text { Medium } \\
(\mathrm{SCM})\end{array}$ & $\begin{array}{l}\text { DMEM/F12 } \\
\text { (Gibco, Life } \\
\text { Technologies) }\end{array}$ & $\begin{array}{l}20 \% \text { (v/v) knock-out serum replacement } \\
\text { (KSR, Life Technologies) } \\
1 \%(\mathrm{v} / \mathrm{v}) \text { non-essential amino acids (NEAA, } \\
\text { Life Technologies) } \\
4 \mathrm{ng} / \mathrm{mL} \text { bFGF (Life Technologies) } \\
5 \mathrm{ng} / \mathrm{mL} \text { hLIF (New England Biolabs, UK) } \\
20 \mathrm{ng} / \mathrm{mL} \text { gentamicin, } 0.5 \mathrm{ng} / \mathrm{mL} \\
\text { amphotericin B (Life Technologies) }\end{array}$ & {$[36,37]$} \\
\hline $\begin{array}{l}\text { Endothelial } \\
\text { Growth } \\
\text { Media } \\
\text { (EGM) }\end{array}$ & $\begin{array}{l}\text { EBM-2 Basal } \\
\text { Medium } \\
\text { (Lonza, } \\
\text { Belgium) }\end{array}$ & EGM-2 SingleQuot Kit (CC-4147, Lonza) & {$[38]$} \\
\hline MethoCult ${ }^{\mathrm{TM}}$ & $\begin{array}{l}\text { MethoCult }{ }^{\circledR} \\
\text { H4034 } \\
\text { Optimum } \\
\text { (STEMCELL } \\
\text { Technologies, } \\
\text { UK) }\end{array}$ & $\begin{array}{l}20 \mathrm{ng} / \mathrm{mL} \text { gentamicin, } 0.5 \mathrm{ng} / \mathrm{mL} \\
\text { amphotericin B (Life Technologies) }\end{array}$ & {$[65]$} \\
\hline $\begin{array}{l}\text { Keratinocyte } \\
\text { Serum Free } \\
\text { Medium (K- } \\
\text { SFM) }\end{array}$ & $\begin{array}{l}\text { Keratinocyte- } \\
\text { SFM } \\
\text { (Life } \\
\text { Technologies) }\end{array}$ & $\begin{array}{l}\text { Keratinocyte Supplement (Bovine Pituitary } \\
\text { Extract, Epidermal Growth Factor (EGF), } \\
\text { Life Technologies) } \\
20 \mathrm{ng} / \mathrm{mL} \text { gentamicin, } 0.5 \mathrm{ng} / \mathrm{mL} \\
\text { amphotericin B (Life Technologies) }\end{array}$ & {$[24,34]$} \\
\hline $\begin{array}{l}\text { StemPro®- } \\
34\end{array}$ & $\begin{array}{l}\text { StemPro®)-34 } \\
\text { Serum Free } \\
\text { Medium } \\
\text { (Life } \\
\text { Technologies }\end{array}$ & $\begin{array}{l}\text { StemPro®-34 Nutrient Supplement } \\
20 \mathrm{ng} / \mathrm{mL} \text { gentamicin, } 0.5 \mathrm{ng} / \mathrm{mL} \\
\text { amphotericin B (Life Technologies) }\end{array}$ & [66] \\
\hline
\end{tabular}

URL: http://mc.manuscriptcentral.com/cytotherapy E-mail: cytotherapy@bellsouth.net 
Table 2. Details of antibodies used in immunocytochemistry

\begin{tabular}{|c|c|c|c|c|}
\hline Antigen & Clone & Source (Catalogue \#) & Host & Conjugate \\
\hline Vimentin & V9 & Vector Labs (VPV684) & Mouse & - \\
\hline CD34 & QBEND10 & Abcam (Ab8536) & Mouse & - \\
\hline CD105 & Polyclonal & R\&D Systems (AF1097) & Goat & - \\
\hline CD90 & F15-42-1 & $\begin{array}{l}\text { Thermo Scientific Pierce (MA5- } \\
\text { 16671) }\end{array}$ & Mouse & - \\
\hline CD73 & Polyclonal & Abcam (Ab71322) & Rabbit & - \\
\hline $\mathrm{ABCG} 2$ & $5 \mathrm{D} 3$ & R\&D Systems (MAB995) & Mouse & - \\
\hline ALDH3A1 & Polyclonal & Abcam (ab76976) & Rabbit & - \\
\hline Keratocan & Polyclonal & $\begin{array}{l}\text { Santa Cruz Biotechnology (sc- } \\
\text { 33243) }\end{array}$ & Goat & - \\
\hline SSEA-4 & MC813-70 & R\&D Systems (MAB1435) & Mouse & - \\
\hline$\alpha-\mathrm{SMA}$ & $1 \mathrm{~A} 4$ & Abcam (ab7817) & Mouse & - \\
\hline Oct-4A & 653108 & R\&D Systems (MAB17591) & Mouse & - \\
\hline PAX6 & Polyclonal & $\begin{array}{l}\text { Thermo Scientific Pierce (PA5- } \\
\text { 25970) }\end{array}$ & Rabbit & \\
\hline Mouse IgG & Polyclonal & Life Technologies (A-21202) & Donkey & $\begin{array}{l}\text { Alexa } \\
\text { Fluor-488 }\end{array}$ \\
\hline Goat IgG & Polyclonal & Life Technologies (A-11056) & Donkey & $\begin{array}{l}\text { Alexa } \\
\text { Fluor-546 }\end{array}$ \\
\hline Rabbit IgG & Polyclonal & Life Technologies (A-10040) & Donkey & $\begin{array}{l}\text { Alexa } \\
\text { Fluor-546 }\end{array}$ \\
\hline
\end{tabular}

URL: http://mc.manuscriptcentral.com/cytotherapy E-mail: cytotherapy@bellsouth.net 


\section{Figure Legends}

Figure 1. Effect of culture medium on proliferation of CSSC. Cells were cultured in (a) DMEM (b) M199 (c) SCM (d) EGM (e) MethoCult (f) K-SFM (g) StemPro-34. Graph shows number of P0 cells cultured in different media at day 1, 3, 7 and 10. Data shown as mean \pm SEM of 3 independent experiments each with 3 replicates $(n=3)$.

\section{Figure 2. Effect of culture medium on morphology and cytoskeletal arrangements of} CSSC. Cells were cultured in (a) DMEM (b) M199 (c) SCM (d) EGM (e) MethoCult (f) KSFM (g) StemPro-34. (A) Phase contrast images at day 5 (scale bar=90 $\mu \mathrm{m}$ ). (B) F-Actin (green) staining counterstained with DAPI (blue) (scale bar=100 $\mu \mathrm{m}$ ). (C) Vimentin (red) staining counterstained with DAPI (blue) (scale bar=100 $\mu \mathrm{m}$ ). (D) Merged F-Actin, vimentin, DAPI staining taken at low magnification $(x 40$, scale bar $=500 \mu \mathrm{m})$.

Figure 3. Effect of culture medium on mesenchymal stem cell markers. Cells were cultured in (A) DMEM (B) M199 (C) SCM (D) EGM (E) MethoCult (F) K-SFM. Immunocytochemistry was performed for (a) CD34, green; (b) CD105, red; (c) CD90, green; and (d) CD73, red. Negative control images (secondary antibody only) of (e) donkey antimouse IgG Alexa Fluor-488, (f) donkey anti-goat IgG Alexa Fluor-546 (g) donkey anti-rabbit IgG Alexa Fluor-546. All images shown with DAPI counterstain (blue), scale bar=100 $\mu \mathrm{m}$.

Figure 4. Quantification of number of cells expressing mesenchymal stem cells markers. Immunocytochemistry images were quantified to calculate the number of cells in each media expressing (A) CD34, (B) CD105, (C) CD90 and (D) CD73. Data shown as mean \pm SD of 3 independent experiments $(n=3)$. Statistical significances comparing each media to each other are shown in the table below each graph: ns, non-significant, ${ }^{*} \mathrm{p} \leq 0.05,{ }^{*} \mathrm{p} \leq 0.01$, $* * * \mathrm{p} \leq 0.001, * * * * \mathrm{p} \leq 0.0001$ (one-way ANOVA)

URL: http://mc.manuscriptcentral.com/cytotherapy E-mail: cytotherapy@bellsouth.net 
Figure 5. Effect of culture medium on pluripotency and keratocyte markers. Cells were cultured in (A) DMEM (B) M199 (C) SCM (D) EGM (E) MethoCult (F) K-SFM. Immunocytochemistry was performed for (a) ABCG2, green; (b) Keratocan, green; (c) SSEA-4, green; (d) Oct-4A, red and (e) Pax6, red. Negative controls (secondary antibody only) can be seen in figure 3. All images shown with DAPI counterstain (blue), scale bar=100 $\mu \mathrm{m}$.

Figure 6. Quantification of cell number expressing pluripotency and keratocyte markers. Immunocytochemistry images were quantified to calculate the number of cells in each media expressing (A) ABCG2, (B) Keratocan, (C) SSEA-4, (D) Oct-4A and (E) Pax6. Data shown as mean \pm SD of 3 independent experiments $(n=3)$. Statistical significances comparing each media to each other are shown in the table below each graph: ns, nonsignificant, ${ }^{*} \mathrm{p} \leq 0.05, * * \mathrm{p} \leq 0.01, * * * \mathrm{p} \leq 0.001, * * * * \mathrm{p} \leq 0.0001$ (one-way ANOVA).

Figure 7. Comparative effect of culture medium on gene expression of CSSC. CSSC were continually cultured in DMEM, M199, SCM, EGM or MethoCult to P2. Relative levels of mRNA were determined by RT-qPCR for the following genes (a) CD34 (b) THY1, (c) POU5F1 and (d) PAX6. Expression of each target gene is normalised to GAPDH and represented relative to mRNA expression in DMEM. Data shown as mean \pm SEM of 3 independent experiments $(n=3)$, each with 3 replicates. Statistical significance vs. DMEM ${ }^{*} \mathrm{p} \leq 0.05, * * \mathrm{p} \leq 0.01, * * * \mathrm{p} \leq 0.001, * * * * \mathrm{p} \leq 0.0001$ (one-way ANOVA).

Figure 8. Effect of culture medium on differentiation back to a keratocyte phenotype. CSSC at P3 were differentiated back to a keratocyte phenotype using a serum-free medium containing bFGF, for 21 days. Immunocytochemistry was performed for (A) ALDH3A1, (B) a-SMA, (C) CD34 on non-differentiated control samples (i-v) and differentiated samples (vix). CSSC had ben propagated in DMEM, M199, SCM, EGM or MethoCult prior to

URL: http://mc.manuscriptcentral.com/cytotherapy E-mail: cytotherapy@bellsouth.net 
differentiation. All images shown with DAPI counterstain (blue), scale bar=100 $\mu \mathrm{m}$. Relative levels of mRNA were determined by RT-qPCR for the following genes (D) ALDH3A1 (E) ACTA2 (F) CD34 (G) KERA and (H) COL1A1. Expression of each target gene is normalised to $G A P D H$ and represented relative to mRNA expression in the non-differentiated control of that media. Data shown as mean \pm SEM of 3 independent experiments $(n=3)$, each with 2 replicates. Statistical significance vs. control ${ }^{*} \mathrm{p} \leq 0.05, * * \mathrm{p} \leq 0.01, * * * \mathrm{p} \leq 0.001, * * * * \mathrm{p} \leq 0.0001$ (two-way ANOVA).

URL: http://mc.manuscriptcentral.com/cytotherapy E-mail: cytotherapy@bellsouth.net 

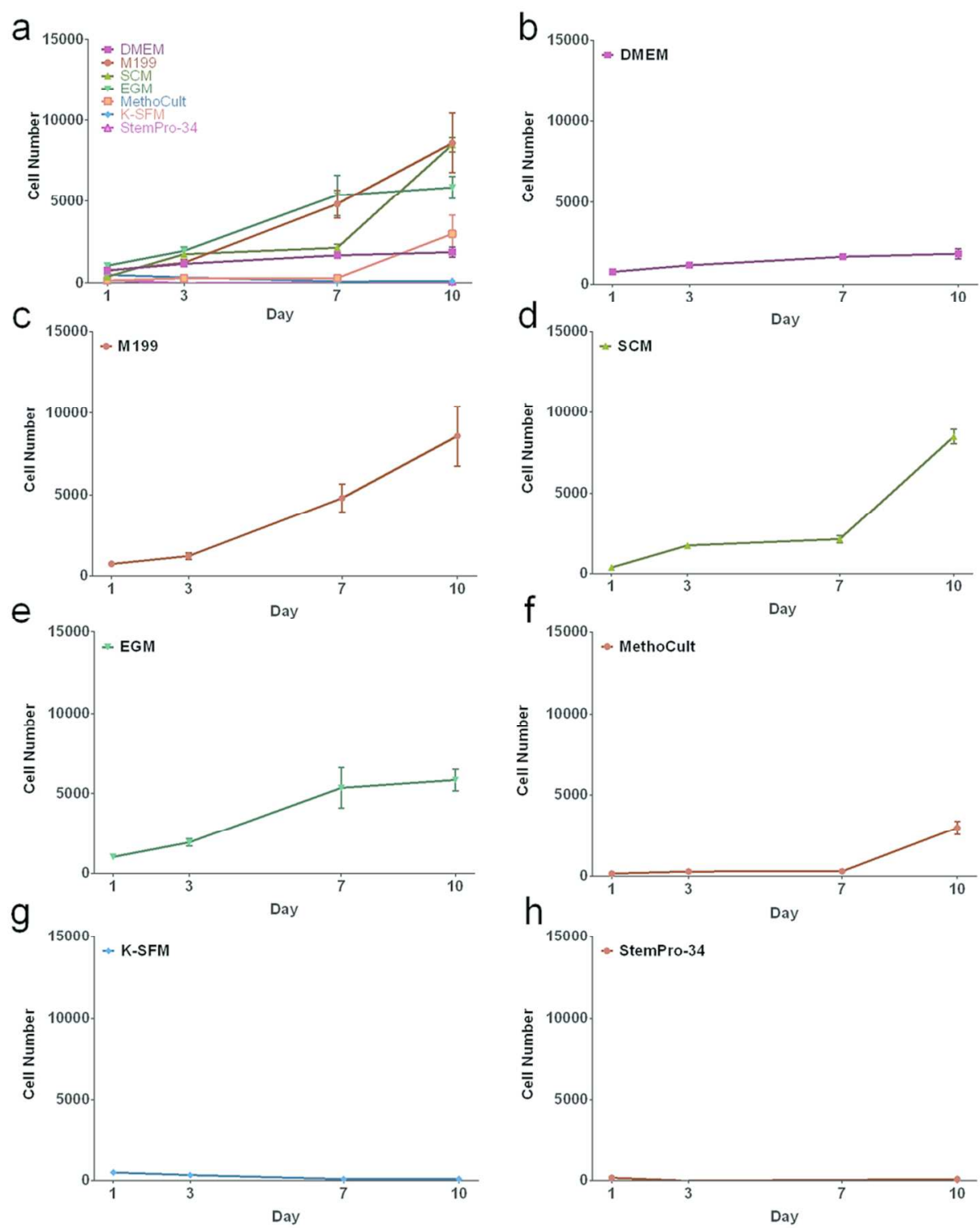

Figure 1. Effect of culture medium on proliferation of CSSC. Cells were cultured in (a) DMEM (b) M199 (c) SCM (d) EGM (e) MethoCult (f) K-SFM (g) StemPro-34. Graph shows number of P0 cells cultured in different media at day 1, 3, 7 and 10. Data shown as mean \pm SEM of 3 independent experiments each with 3 replicates $(n=3)$. $119 \times 144 \mathrm{~mm}(300 \times 300 \mathrm{DPI})$

URL: http://mc.manuscriptcentral.com/cytotherapy E-mail: cytotherapy@bellsouth.net 


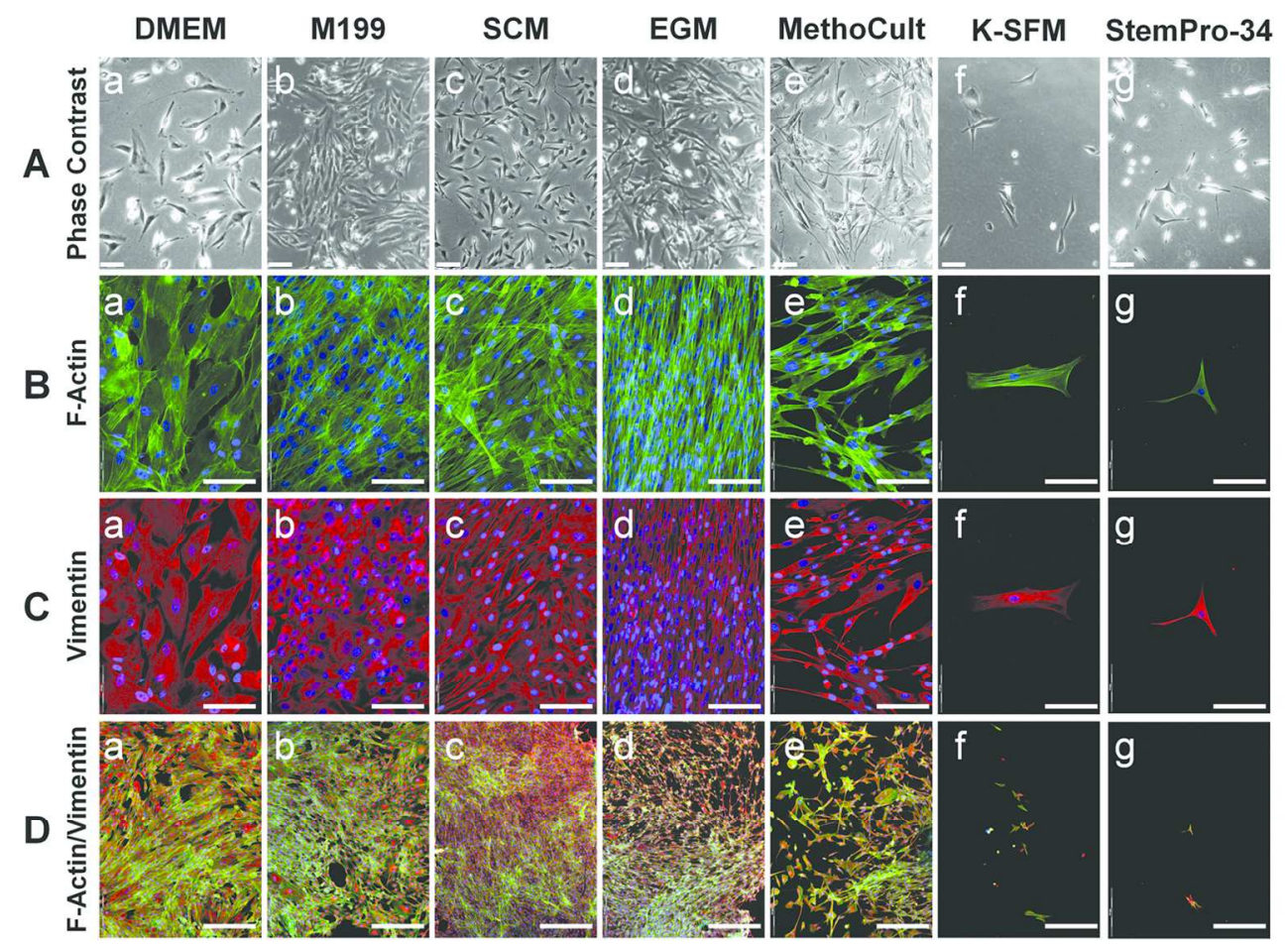

Figure 2. Effect of culture medium on morphology and cytoskeletal arrangements of CSSC. Cells were cultured in (a) DMEM (b) M199 (c) SCM (d) EGM (e) MethoCult (f) K-SFM (g) StemPro-34. (A) Phase contrast images at day 5 (scale bar $=90 \mu \mathrm{m}$ ). (B) F-Actin (green) staining counterstained with DAPI (blue) (scale bar $=100 \mu \mathrm{m}$ ). (C) Vimentin (red) staining counterstained with DAPI (blue) (scale bar=100 $\mu \mathrm{m})$. (D) Merged F-Actin, vimentin, DAPI staining taken at low magnification ( $x 40$, scale bar=500 $\mu \mathrm{m}$ ). $140 \times 104 \mathrm{~mm}(300 \times 300 \mathrm{DPI})$ 


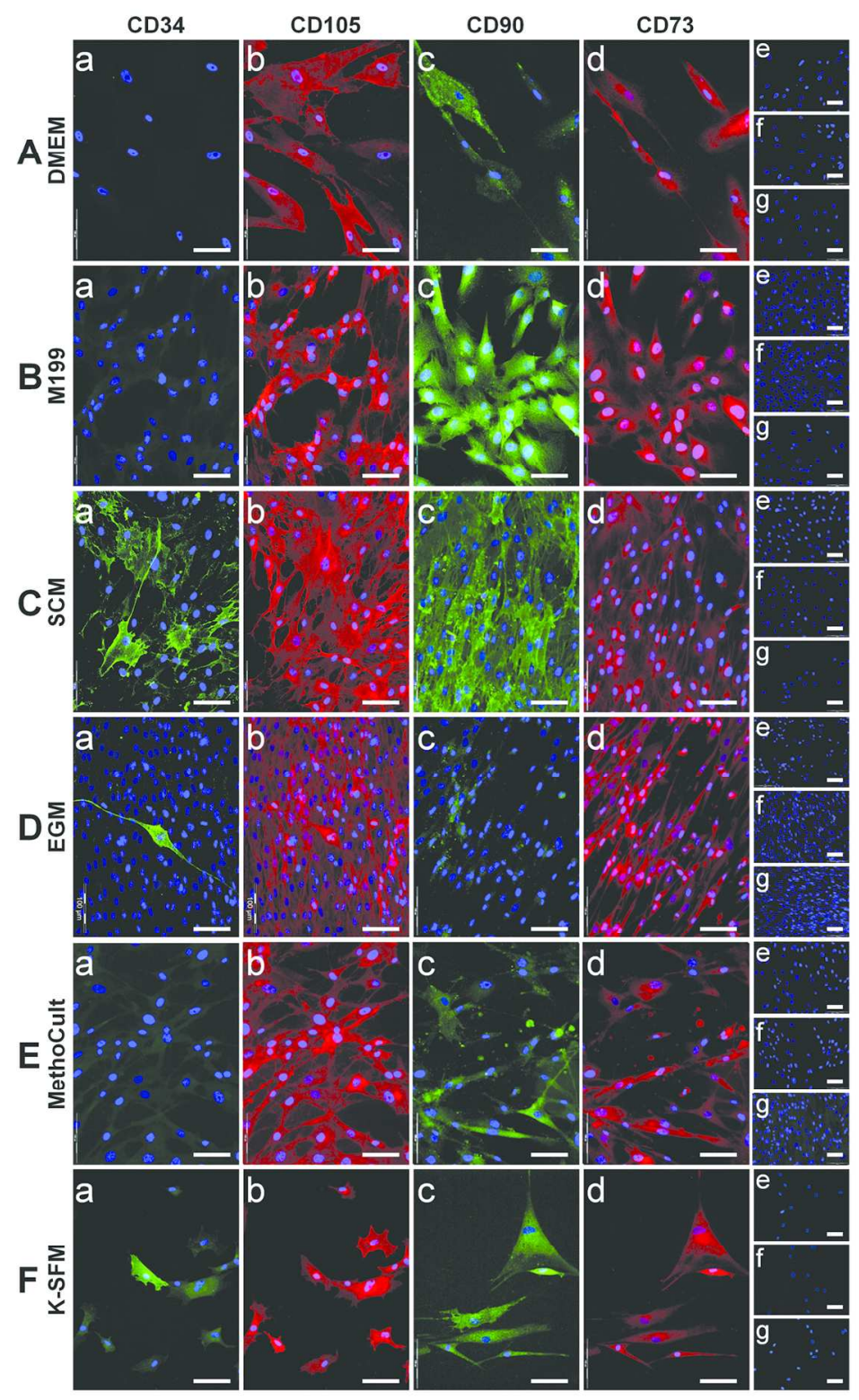

Figure 3. Effect of culture medium on mesenchymal stem cell markers. Cells were cultured in (A) DMEM (B) M199 (C) SCM (D) EGM (E) MethoCult (F) K-SFM. Immunocytochemistry was performed for (a) CD34, green; (b) CD105, red; (c) CD90, green; and (d) CD73, red. Negative control images (secondary antibody only) of (e) donkey anti-mouse IgG Alexa Fluor-488, (f) donkey anti-goat IgG Alexa Fluor-546 (g) donkey anti-rabbit IgG Alexa Fluor-546. All images shown with DAPI counterstain (blue), scale bar=100 $\mu \mathrm{m}$. $119 \times 195 \mathrm{~mm}(300 \times 300 \mathrm{DPI})$ 

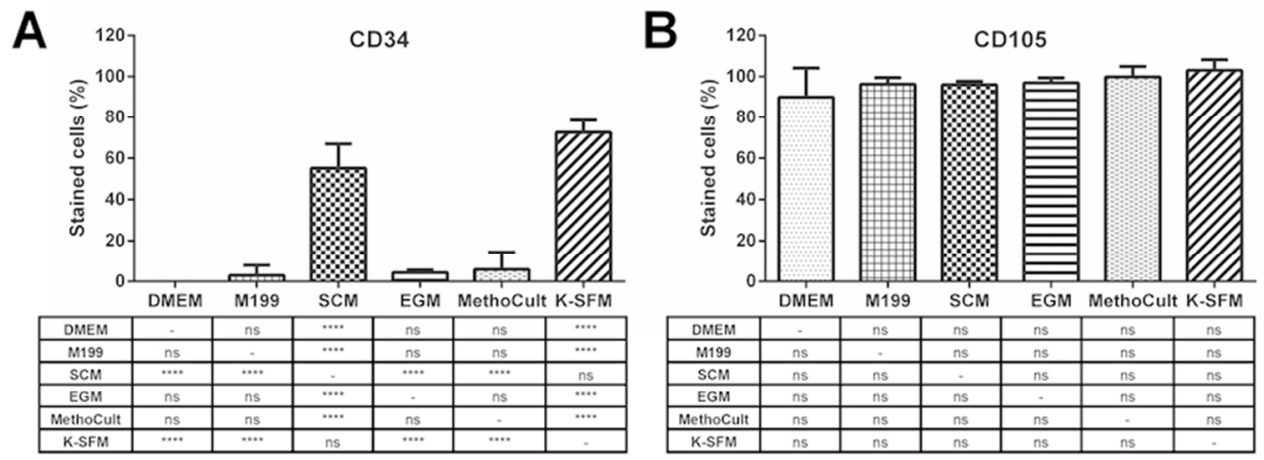

C

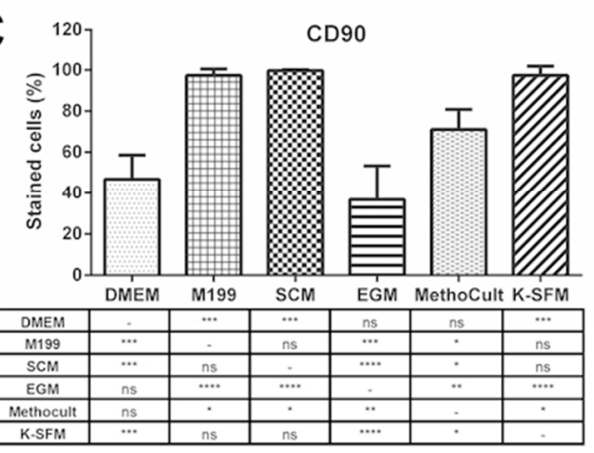

D

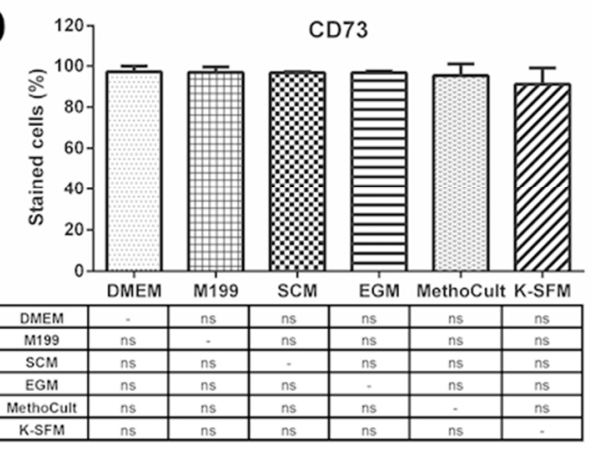

Figure 4. Quantification of number of cells expressing mesenchymal stem cells markers. Immunocytochemistry images were quantified to calculate the number of cells in each media expressing (A) CD34, (B) CD105, (C) CD90 and (D) CD73. Data shown as mean \pm SD of 3 independent experiments $(n=3)$. Statistical significances comparing each media to each other are shown in the table below each graph: ns, non-significant, $* p \leq 0.05, * * p \leq 0.01, * * * p \leq 0.001, * * * * p \leq 0.0001$ (one-way ANOVA). $80 \times 59 \mathrm{~mm}(300 \times 300 \mathrm{DPI})$ 


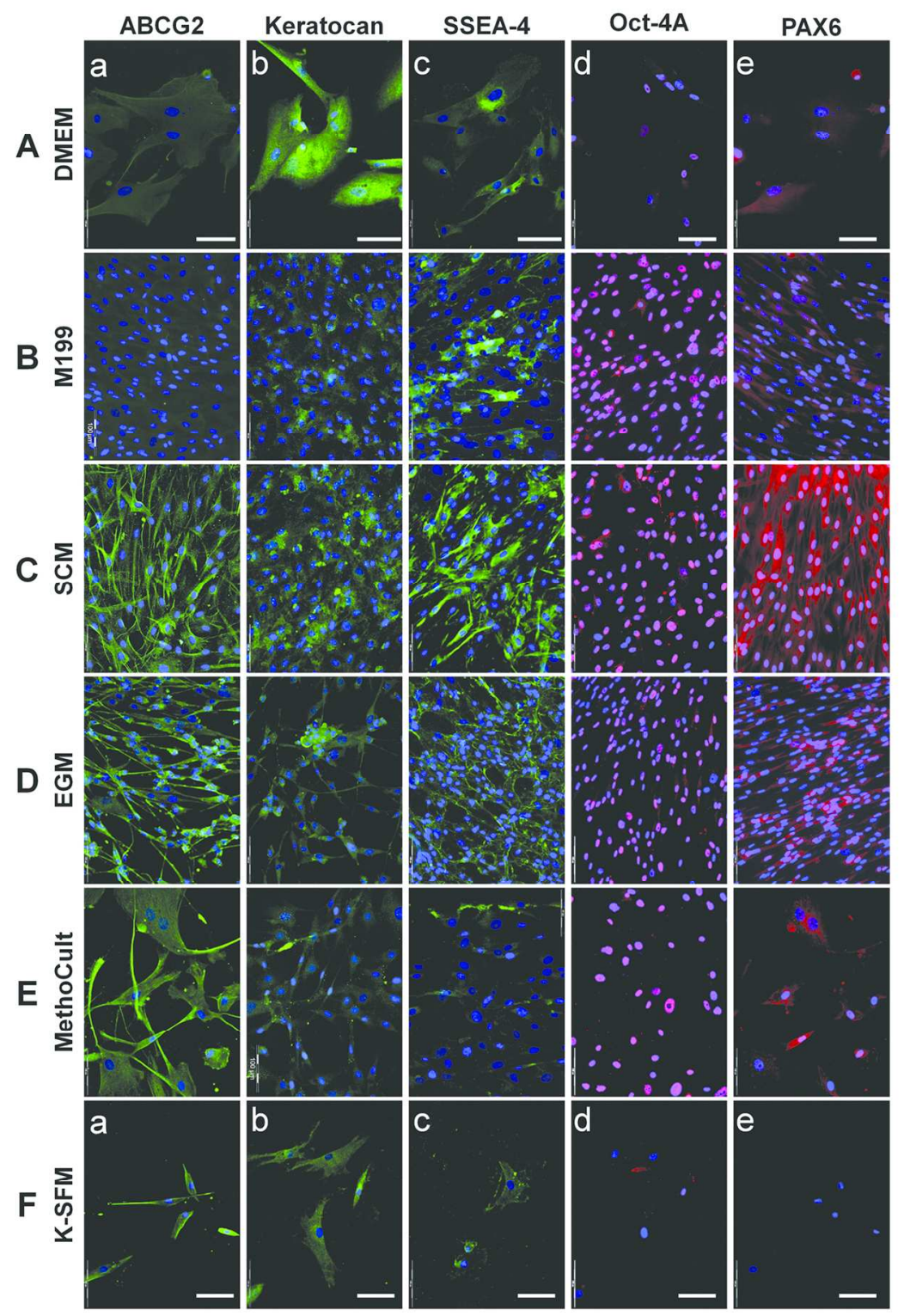

Figure 5. Effect of culture medium on pluripotency and keratocyte markers. Cells were cultured in (A) DMEM (B) M199 (C) SCM (D) EGM (E) MethoCult (F) K-SFM. Immunocytochemistry was performed for (a) ABCG2, green; (b) Keratocan, green; (c) SSEA-4, green; (d) Oct-4A, red and (e) Pax6, red. Negative controls (secondary antibody only) can be seen in figure 3. All images shown with DAPI counterstain (blue), scale bar $=100 \mu \mathrm{m}$.

$119 \times 179 \mathrm{~mm}(300 \times 300 \mathrm{DPI})$ 


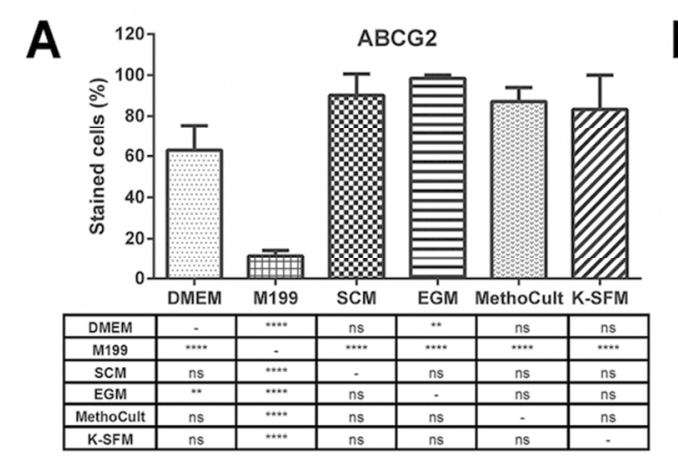

B

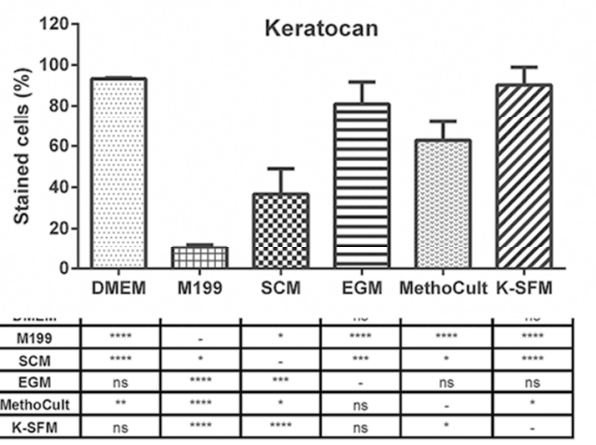

C

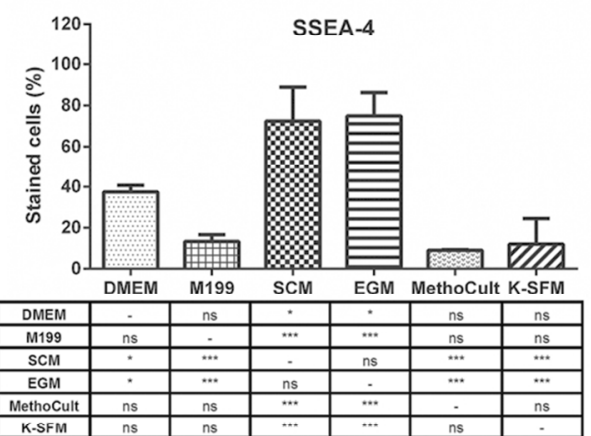

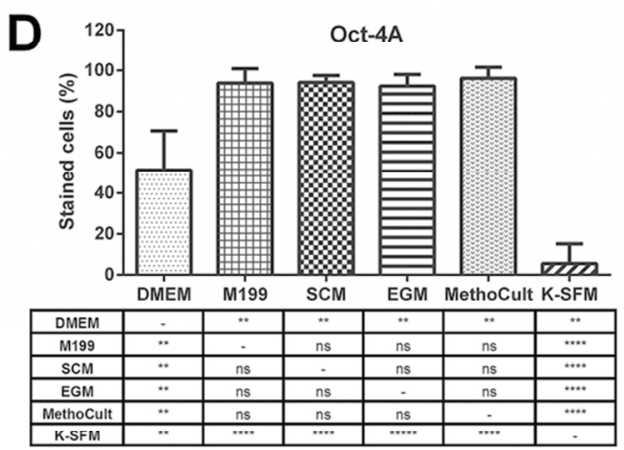

E

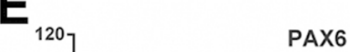
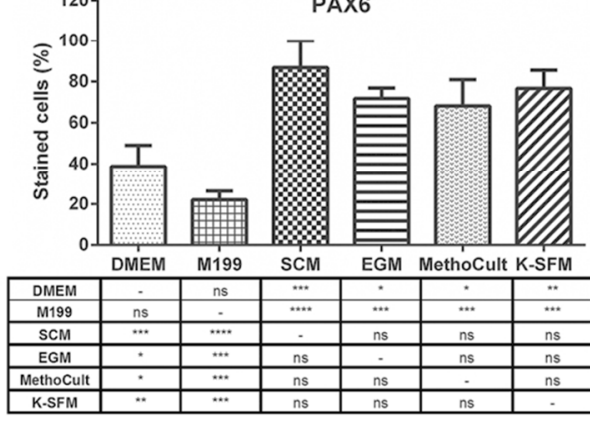

Figure 6. Quantification of cell number expressing pluripotency and keratocyte markers. Immunocytochemistry images were quantified to calculate the number of cells in each media expressing (A) ABCG2, (B) Keratocan, (C) SSEA-4, (D) Oct-4A and (E) Pax6. Data shown as mean \pm SD of 3 independent experiments $(n=3)$. Statistical significances comparing each media to each other are shown in the table below each graph: ns, non-significant, $* p \leq 0.05, * * p \leq 0.01, * * * p \leq 0.001, * * * * p \leq 0.0001$ (one-way ANOVA). $99 \times 109 \mathrm{~mm}(300 \times 300 \mathrm{DPI})$ 
a

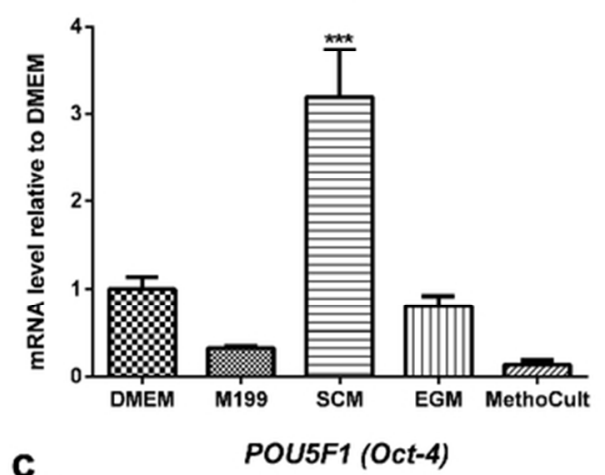

C

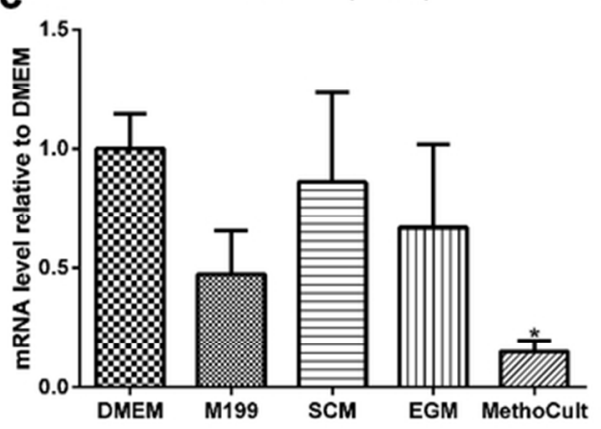

b $\quad T H Y 1(C D 90)$
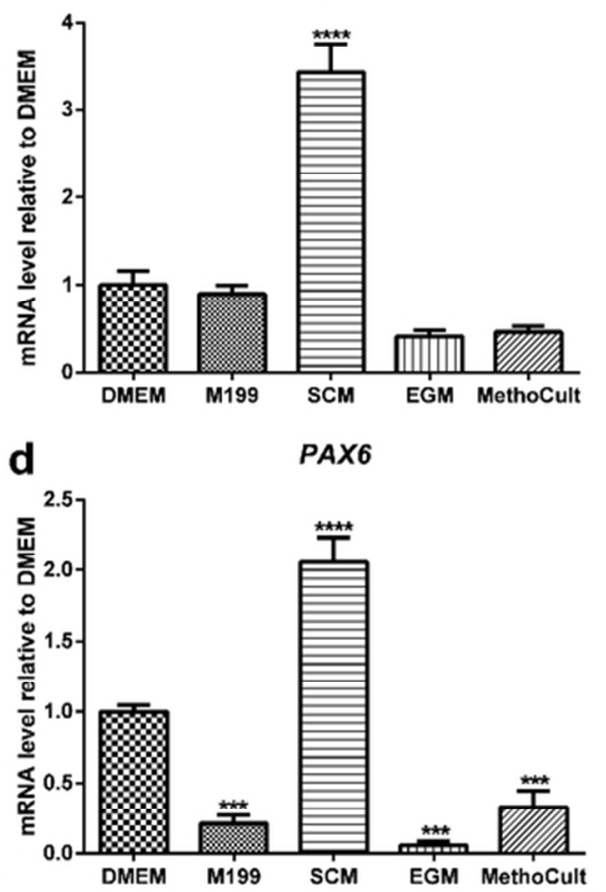

Figure 7. Comparative effect of culture medium on gene expression of CSSC. CSSC were continually cultured in DMEM, M199, SCM, EGM or MethoCult to P2. Relative levels of mRNA were determined by RT-qPCR for the following genes (a) CD34 (b) THY1, (c) POU5F1 and (d) PAX6. Expression of each target gene is normalised to GAPDH and represented relative to mRNA expression in DMEM. Data shown as mean \pm SEM of 3 independent experiments $(n=3)$, each with 3 replicates. Statistical significance vs. DMEM *p $\leq 0.05$, $* * \mathrm{p} \leq 0.01, * * * \mathrm{p} \leq 0.001, * * * * \mathrm{p} \leq 0.0001$ (one-way ANOVA). $62 \times 48 \mathrm{~mm}(300 \times 300 \mathrm{DPI})$ 

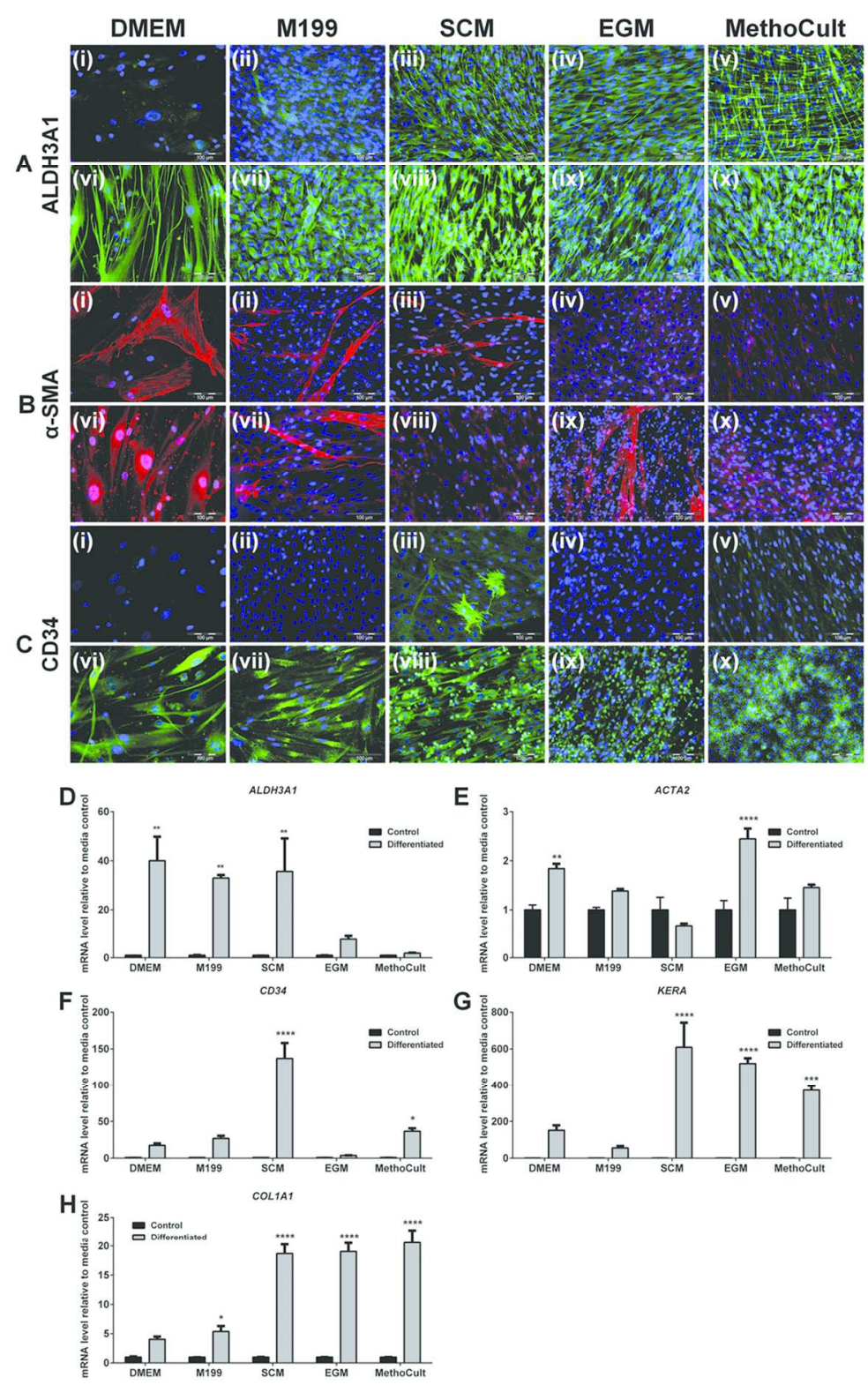

Figure 8. Effect of culture medium on differentiation back to a keratocyte phenotype. CSSC at P3 were differentiated back to a keratocyte phenotype using a serum-free medium containing bFGF, for 21 days. Immunocytochemistry was performed for (A) ALDH3A1, (B) a-SMA, (C) CD34 on non-differentiated control samples (i-v) and differentiated samples (vi-x). CSSC had ben propagated in DMEM, M199, SCM, EGM or MethoCult prior to differentiation. All images shown with DAPI counterstain (blue), scale bar $=100 \mu \mathrm{m}$. Relative levels of mRNA were determined by RT-qPCR for the following genes (D) ALDH3A1 (E) ACTA2 (F) CD34 (G) KERA and (H) COL1A1. Expression of each target gene is normalised to GAPDH and represented relative to mRNA expression in the non-differentiated control of that media. Data shown as mean $\pm \mathrm{SEM}$ of 3 independent experiments $(n=3)$, each with 2 replicates. Statistical significance vs. control $* p \leq 0.05$, $* * p \leq 0.01, * * * p \leq 0.001, * * * * p \leq 0.0001$ (two-way ANOVA). $95 \times 150 \mathrm{~mm}(300 \times 300 \mathrm{DPI})$ 